\title{
SME Growth: The Role of Government Grant
}

\author{
Andrea Quintiliani \\ Assistant Professor \\ Department of Law and Economic Sciences, Pegaso Telematic University, Naples, Italy \\ E-mail: andrea.quintiliani@unipegaso.it
}

Received: Oct. 7, 2017 Accepted: Nov. 24, $2017 \quad$ Published: December 1, 2017

doi:10.5296/ajfa.v9i2.12237 URL: https://doi.org/10.5296/ajfa.v9i2.12237

\begin{abstract}
The objectives of this research are two: to understand, if Government grants create favorable conditions for enterprises which mean to promote diversification process by increasing range of company products; and to understand if diversification strategy, stimulated by public grants, can lead to a growth of company value. This research is carried out through the balance sheets of the data-base AIDA and analysis of questionnaires submitted to a sample of 100 small and medium-sized enterprises located in Molise Region (Italy), operating in the agro-alimentary sector, and which benefited from public grants during the period 2007-2008. The analysis covering the period 2003-2014. The empirical evidence from January 2003 to December 2014 indicates a strong relationship between Government grant, strategy diversification and growth of enterprise value. It should be emphasized that present work limits its field of investigation to a few variables without fully addressing other elements of uncertainty that may adversely affect on SME's EVA. This work will be useful to stimulate debate on policies to support SMEs. The originality of this study is the correlation between public grants, corporate strategies and added economic value.
\end{abstract}

Keywords: diversification strategy, financial performance, government grant, EVA, enterprise value

JEL Classification: G32, G38, L25 


\section{Introduction}

In business literature there is a significant presence of studies regarding product differentiation and optimizing resources to attain it, as diversification is too expensive to carry out and often requires vast resources (internal and external).

However, the analyses which investigate the role of financing of these diversification strategies, has been less explored. As a result, it seemed interesting to examine the links between the politics of diversification and the characteristics of the financial resources, which they sustained with a particular regard to Government grant.

Most famous studies have demonstrated that financing decisions could be "irrelevant" in the process of company strategies (Modigliani and Miller, 1958), but a change in the company working conditions has shown that these decisions can affect the value of the company, because of market imperfections, highlighting the role of finance in the implementation of business strategies (Myers and Majluf, 1984).

A large number of studies have supported a link between decisions and financing sources in the formulation of a business strategy (Barton and Gordon, 1988; Bromiley, 1990; Chatterjee, 1990; Chatterjee and Wernerfelt, 1991; Kochhar, 1996) enhancing the importance of funding in firms development strategies (Jensen, 1986).

On the other hand, a series of studies postulated that diversification is not associated to the type of funding (Ramanujam and Varadarajan, 1989; Chatterjee and Singh, 1995) or that the nature of diversification depends, in part, on the financing sources available to the firm (Chatterjee and Wernerfelt, 1991). Given the necessity and the substantial endowment of financing sources required by a strategic process of product differentiation, many companies must turn to external financing.

Finally, from a methodological point of view, the importance of studies analyzing the company value generated by diversification (Guatri, 1991; Ezzamel, 1996; Donna, 1999; Bennet Stewart, 2000; Copeland et al., 2002; Di Lazzaro, 2003; Lothian, 2005) appears relevant because the instruments for measuring strategic performances induced by Government grant, object of the study, can be placed in this work.

In this work we use Economic Value Added (EVA) as indicator of performance to evaluate the value generated by corporate strategies. Economic Value Added is an important indicator to measure the creation of current and potential value, therefore, to give concrete implementation to the business strategies that have the founding objective in the creation of value.

As evidenced by study of Unnisa and Janakiramudu (2014): «Economic Value Added (EVA) is the best available measure for evaluating shareholders value. It is a measure of economic profit and not accounting profit. EVA calculation shows the difference between the cost of capital and the return on that capital. The shareholders of the company invest with the aim of getting return and increase in the value».

For further information on economic value added concept, following studies are suggested: 
Bennet Stewart, 1991; Brealey and Myers, 1991; Stern et al., 2001; Grant, 2003; Ray, 2012; Shil, 2009).

Based on aforementioned scenario this study focusing on the analysis of relationships between diversification strategies, Government grant and company value. In particular, the following research questions are formulated as below:

1) Is there a direct relationship between Government grant given to the firm and the diversification strategy adopted?

2) Is it possible to measure quantitatively the benefits that diversification strategy can bring to the growth of company value?

\section{Method}

This project, initiated in 2015, analysed a sample of enterprises of the Molise Region, operating in the agro-alimentary industry, to collect qualitative data such as: the institutional and organisational set-up, the competitive level in the markets, development strategies and the modalities to access Government grants. Qualitative data have been collected through questionnaires.

The enterprises, which participated in this project, belong to a sample of 180 companies selected according to the following research criteria:

a) the enterprises were working in the agro-alimentary industry;

b) they were operating between 2003 and 2014;

c) they were not dependent by parent companies. This further research key has allowed the balance sheet analyst to get around problems related to intra-group transactions;

d) they were small and medium-sized. All of the interviewed enterprises respect quantitative parameters imposed by the European Union for the classification of small and medium-sized enterprises (number of employees under 250 and turnover less than 40 million Euro);

e) they have benefitted from Government grants in the period 2007-2008 (Interest Subsidies, Operating Expenses Subsidies, Capital Subsidies and Investment Subsidies). The interest subsidy is a benefit, generally middle or long term, conceded against a financing granted by authorized subjects working in the banking system. It can be issued in two ways. In the first case, it acts upon the financial contract initially stipulated according to market conditions, cutting down interest rates. In the second case, the financing provides a soft tax from the beginning. Subsidies for operating costs have the function to cut down on operating costs, capital subsidies aim to enlarge the enterprise wealth but do not oblige a specific investment while investment subsidies are granted specifically in relation to the acquisition of depreciable assets. 
Presently, the research has overall updated the database of 100 enterprises from the Molise Region while for the remaining 80 enterprises the interview phase has yet to be completed.

Research data were collected using questionnaires and balance sheets.

The questions on the questionnaire with fixed answers were directed to investigate:

- competitive characteristics;

- organizational structure;

- $\quad$ adopted development strategies;

- qualitative and quantitative variables concerning Government grants.

\section{Results}

The quantitative analysis of the enterprise balance sheet.

In order to develop the quantitative analyses of the study, a known method of calculating company value EVA - Economic Value Added -has been used (Bennet Stewart, 2000).

The fundamental concept, on which modern financial theory is based, is that an enterprise is economically profitable if it produces a superior return to the financial funds it uses. Even if this statement seems obvious, even more often the success of an enterprise is measured with regards to profitable gains, return on equity (ROE), rate of growth, cash-flow, gross operative margin, market share and in the case of listed enterprises the relationship between price and earnings (P/E), and earnings per share (EPS). Even if all of these elements are relevant to the performance evaluation, none of them refers directly to the concept here expressed and it is highly possible that enterprises with a high growth level of ROE, P/E, etc. do not have a high economic return rate.

On the contrary, EVA measures economic return directly,

$$
\mathrm{EVA}=\mathrm{K} \times(\mathrm{r}-\mathrm{c})
$$

Where " $\mathrm{K}$ " stands for the invested capital (financial resources used in the enterprise), " $\mathrm{r}$ " is the rate of return on invested capital and "c" (or WACC) is the cost of the capital.

The capital invested is the sum of the economic value of money invested in various forms in the enterprise while the rate of return on invested capital is calculated by dividing the net operating profit after taxes (NOPAT) for the invested capital. NOPAT in return can be seen as the difference between net operating profits (inclusive of amortization) and "cash operating taxes".Even NOPAT is subject to a multiplicity of adjustments, which vary according to the method of accounting used for the stock, to the presence in the balance of amortization for the start-up of acquired societies, the capitalization of research costs. This is naturally only an indication: the true objective is to single out the relationship between enterprise debt and capital in an average period. NOPAT is therefore a measure of the earning performance of an enterprise, which contrary to ROE, it is independent from financial structure. It can be easily shown that with equal operating results, an indebted enterprise 
tends to show a higher ROE and vice versa. NOPAT in this case would remain unvaried. The rate of capital return $(r)$ can therefore be calculated as: $r=N O P A T \div K$.

The cost of capital represents conceptually the minimum return requested by shareholders and creditors to compensate the risk they run and can be calculated in various ways.

This study used a method commonly used by external financial analysists called CAPM (Capital Asset Pricing Model) in circulation for more than a quarter of a century, but still used.

The relationship between enterprise debt and capital is calculated on a time of 2 years (about this aspect, it is only an indication; the true aim is the individuation of ratio Debt-Capital of enterprise of middle period) and then the remuneration requested by the enterprise shareholders is calculated in the following way:

$$
y=r_{f}+\beta \times\left(r_{m}-r_{f}\right)
$$

Where "rf" represents the return on long-term government securities, "rm" represents the rate of return on the stock market and " $\beta$ " represents the riskiness of the enterprise with regard to the stock market.

The return on long-term government securities affects the average interest rate of ten-year Treasury bonds. The source of data is the State Treasury's official internet site. The rate of return on the stock market is calculated as average of ROE on the balance data and afferent to Italian agro-alimentary industry.

Most of the data used in the work are taken from databases AIDA by Bureau Van Dijk. For this study Beta is calculated with the aid of Aswath Damodaran database (Food Processing sector).If $\beta>1$ the enterprise is riskier than the market and viceversa if $\beta<1$. Even if this formula regards the stock market, it can also be used to calculate enterprise value of unlisted companies by making some adjustments. For both the " $\mathrm{r}_{\mathrm{f}}$ " and the " $\mathrm{r}_{\mathrm{m}}$ ", it is appropriate to calculate an average of a time horizon of at least three years.

At this point, the average cost of capital after taxes is calculated in the following way:

$$
\mathrm{c}=[(\mathrm{K}-\mathrm{D}) \times \mathrm{y}+\mathrm{D} \times \mathrm{b} \times(1-\mathrm{t})] \div \mathrm{K}
$$

Where " $\mathrm{D}$ " represents the average of total enterprise debt in two years and " $\mathrm{t}$ " is the rate fiscal taxation.

\section{Emerging data from the sample.}

The following charts show the calculation of all the dimensions presented up to now and afferent to the aggregate enterprise sample. It is presumed that the data has been "adjusted" according to the preceding description. According to the calculations, the aggregate in question realized the following:

- $\quad$ in the period 2003-2004 a negative EVA equal to -2.242.499 with a capital return inferior to $1.37 \%$ with respect to its cost $(-1.37=2.84-4.21)$; 
- $\quad$ in the period 2005-2006 a negative EVA equal to -6.236.067 with a capital return inferior to $3.63 \%$ with respect to its cost $(-3.63=-0.33-3.30)$;

- $\quad$ in the period 2007-2008 a negative EVA equal to -2.866.099 with a capital return inferior to $2.37 \%$ with respect to its cost $(-2.37=1.75-4.12)$;

- $\quad$ in the period 2009-2010 a positive EVA equal to 683.038 with a capital return superior to $0.82 \%$ with respect to its cost $(0.82=6.54-5.72)$;

- $\quad$ in the period 2011-2012 a positive EVA equal to 5.300.169 with a capital return superior to $2.24 \%$ with respect to its cost $(2.24=5.02-2.78)$;

- $\quad$ in the period 2013-2014a negative EVA equal to -4.693.099 with a capital return inferior to $1.14 \%$ with respect to its cost $(-1.14=2.32-3.46)$.

The application of the formula of value creation allows the assessment of which enterprises create value and which destroy it (Tab. 1; Tab.2).

Table 1. Estimation results of EVA

\begin{tabular}{c|llllll}
\hline \multicolumn{1}{c}{ Period } & \multicolumn{1}{c}{$\mathrm{K}$} & $\mathrm{r}$ & & $\mathrm{c}$ & \multicolumn{1}{c}{ NOPAT } & \multicolumn{1}{c}{ EVA } \\
\hline $2003-2004$ & $1.636 .860,58$ & 2,84 & 4,21 & $4.648 .684,06$ & $-2.242 .499,00$ \\
$2005-2006$ & $2.099 .685,86$ & 0,33 & 3,3 & $692.896,33$ & $-6.236 .067,00$ \\
$2007-2008$ & $1.209 .324,47$ & 1,75 & 4,12 & $2.116 .317,83$ & $-2.866 .099,00$ \\
$2009-2010$ & $832.973,17$ & 6,54 & 5,72 & $5.447 .644,54$ & $683.038,00$ \\
$2011-2012$ & $2.366 .146,88$ & 5,02 & 2,78 & $11.878 .057,31$ & $5.300 .169,00$ \\
$2013-2014$ & $4.116 .753,51$ & 2,32 & 3,46 & $9.550 .868,14$ & $-4.693 .099,00$ \\
\hline
\end{tabular}

Source: our elaboration on "AIDA" data

Table 2. Financial statements data

\begin{tabular}{clllllc}
\hline Period & Net Income & Net Cash flow & Equity capital & Total Assets & ROE & ROA \\
\hline $2003-2004$ & $18.260,00$ & $1.022 .710,49$ & $1.489 .543,13$ & $2.127 .918,76$ & $1,23 \%$ & $0,86 \%$ \\
$2005-2006$ & $15.210,00$ & $152.437,19$ & $1.910 .714,13$ & $2.729 .591,62$ & $0,80 \%$ & $0,56 \%$ \\
$2007-2008$ & $22.000,00$ & $465.589,92$ & $1.100 .485,27$ & $1.572 .121,81$ & $2,00 \%$ & $1,40 \%$ \\
$2009-2010$ & $72.589,00$ & $1.198 .481,80$ & $758.005,59$ & $1.082 .865,12$ & $9,58 \%$ & $6,70 \%$ \\
$2011-2012$ & $225.879,00$ & $2.613 .172,61$ & $2.153 .193,66$ & $3.075 .990,94$ & $10,49 \%$ & $7,34 \%$ \\
$2013-2014$ & $61.458,00$ & $764.069,45$ & $3.746 .245,69$ & $5.351 .779,56$ & $1,64 \%$ & $1,15 \%$ \\
\hline
\end{tabular}

Source: our elaboration on "AIDA" data

The next step in the investigative methodology is to single out how enterprise profits, directly responsible for the measure of enterprise value, are referable to phenomena linked to the generating processes of diversification. For this purpose, figure 1 singles out the variables, which influence enterprise value and our suggested model for the investigation. 


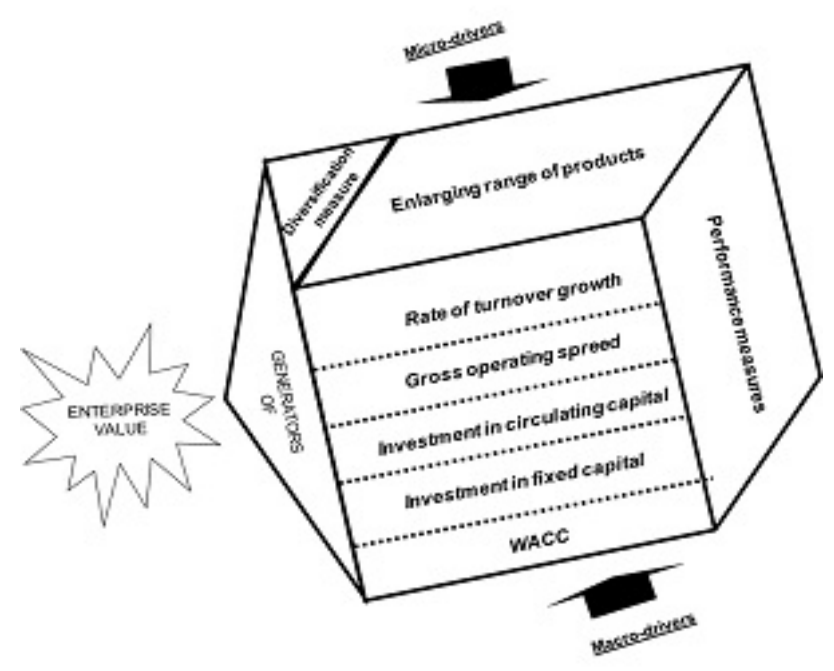

Figure 1. Generators of Enterprise Value

In the construction of a theoretical model, the value is the result of a series of phenomena expressed qualitatively and quantitatively by enterprise management and absolutely interdependent.

The presumption of the analysis is that functional managing facts which generate diversification and measurable with the aid of micro-drivers (having no financial value) influence the macro-drivers (having economical-financial value) as they are destroyers and/or generators of value. In the sphere of diversification measurement, the value micro-drivers are indicators of performance with regards to output parameters and analyzed at the end of the assessment of the level of efficiency of an enterprise system expressed as level of growth of enterprise value.

The following step in defining the investigation is to establish a relationship between macro-drivers and series value micro-drivers.

Our research, with regards to a theoretical model projected and used to demonstrate the relational logic of cause and effect, where financial incentives activators of diversification strategies (and demonstrable with the questionnaires), produce effects on the enterprise value creation, focuses the investigation on the demonstration of the relations relating solely to rate of growth of the turnover linked to the magnitude of the range of company products.

Survey questionnaires highlighted, in synthesis, how Government grants have a significant impact on extent product range.

The results are given table 3 . 
Table 3. Correlation between "Government grant" and "extent product range"

\begin{tabular}{lc}
\hline \multicolumn{1}{c}{ Variable } & $\begin{array}{c}\text { Regression coefficients (t-statistics in } \\
\text { parentheses) }\end{array}$ \\
\hline Statistical relationship between Government grant & 12.5 \\
andextent product range & $(16.8)$ \\
Adjusted-R & 0.3810 \\
\hline
\end{tabular}

Source: our elaboration on survey questionnaires

To understand how the value driver (turnover) relates to diversification (magnitude of product range), the investigation uses an econometric model which allows to evaluate the effect of value creation following a change in the parameter measuring diversification in the sample enterprises.

For this purpose, statistical instruments directed to investigate the sensitivity (ß) of the independent variable (micro-driver) compared to the dependent variable (macro-driver) is used and it is represented in the equation of straight-line regression:

$$
y=a-\beta x
$$

The sensitivity, about the demonstration, is calculated with the following formula:

$$
\beta=\frac{\text { Covariance (magnitude range/products,growth of turnover) }}{\text { Variance (magnitude range/products) }}
$$

The equation of straight line regression, represents the linear function which describes in the best of ways turnover growth (the dependent variable " $y$ " in the equation in question) in function of the level of magnitude of the range of enterprise products (the independent variable " $x$ " on the right-hand side of the equation) and the curve (ß) expresses its sensitivity. Analyzing and interpreting a temporal series (from 2003 to 2014), with annual data of company turnover and magnitude of product range with relative increase or decrease percentage rates, we proceed as follows:

- $\quad Y_{i}=$ growth rates of annual turnover (with $\mathrm{i}=1$ to $\mathrm{n}=789$ );

- $\quad X_{i}=$ growth rate of the range/product (with $i=1$ to $n=789$ ).

The arithmetic average of $\mathrm{X}$ and $\mathrm{Y}$ is calculated as:

$$
\begin{array}{r}
\mu_{x}=\frac{1}{2} \sum_{i=1}^{n=789} x_{i}=0.0175 \\
\mu_{y}=\frac{1}{2} \sum_{i=1}^{n=789} y_{i}=0.0098
\end{array}
$$

From this, the covariance is equal to:

$$
\sigma_{x, y}=\frac{1}{119} \sum_{i=1}^{n=789}\left(x_{i}-\mu_{x}\right)\left(y_{i}-\mu_{y}\right)=0.0017
$$

Given that the variable $\mathrm{x}$ presents $\mathrm{n}$ modalities $\mathrm{x}_{1}, \mathrm{x}_{2}, \mathrm{x}_{3}, \mathrm{n}$ having an average $\mu_{\mathrm{x}}$ the quantity 
takes on the name of the variance defined in this manner:

$$
\sigma_{x}^{2} \frac{\sum_{i=1}^{n=156}\left(x_{i}-\mu_{x}\right)^{2}}{n}=0,0047
$$

Beta is therefore:

$$
\beta=\frac{\text { Covariance (magnitude range/products,growth of turnover) }}{\text { Variance (magnitude range/products) }}=\frac{0.0017}{0.0047}=0.3667
$$

The equation of straight-line regression: $y=0.3667 x+0.0034$ indicates that an increase or decrease of $1 \%$ in the range of enterprise products and that an indicator of the level of enterprise diversification brings on an increase or a decrease of $0.3667 \%$ of turnover.

The coefficient $\mathrm{R}^{2}=0.2286$ indicates, instead, that about $23 \%$ of turnover variation is "explained" by the variation in product range.

To conclude the analysis, the coefficient $\mathrm{R}^{2}$ becomes a parameter to weigh the value system of the economic-financial matrix and measured by EVA.

From this, the expression of the contribution level of "diversification", on company value generated or destroyed.

At this point of the analysis, EVA and the other parameters are re-elaborated with the aid of appropriate weighting $\left(\mathrm{R}^{2}\right)$ and therefore:

$$
\begin{gathered}
\mathrm{NOPAT}_{\mathrm{p}}=\left(\mathrm{NOP} \times \mathrm{R}^{2}\right)-\mathrm{COT} \\
\mathrm{EVA}=\mathrm{K} \times\left(\mathrm{r}_{\mathrm{p}}-\mathrm{c}\right)
\end{gathered}
$$

$\operatorname{NOPAT}_{\mathrm{p}}=$ Weighted Net Operating Profit After Tax; NOP $=$ Net Operating Profit; $\mathrm{R}^{2}=$ Square Error; COT $=$ Cash Operating Taxes; $\mathrm{K}=$ Capital Employed; $r_{p}=$ Return Rate of Capital Employed; $\mathrm{EVA}_{\mathrm{p}}=$ Weighted Economic Value Added.

In our analysis, weighted EVA singles out the value generated by the enterprise sample and attributed to diversification; the latter measured in economical-financial terms by the importance it assumes in the construction of return rate $(r)$, from this weighted $\left(r_{p}\right)$.

The value of weighted EVA is reported as follows (Tab. 4):

- $\quad$ in the period 2003-2004 a negative $\mathrm{EVA}_{\mathrm{p}}$ equal to -740.024;

- $\quad$ in the period 2005-2006 a negative $\mathrm{EVA}_{\mathrm{p}}$ equal to -2.507.903;

- $\quad$ in the period 2007-2008 a negative $\mathrm{EVA}_{\mathrm{p}}$ equal to -945.813;

- $\quad$ in the period 2009-2010 a positive $\mathrm{EVA}_{\mathrm{p}}$ equal to 225.402 ;

- $\quad$ in the period 2011-2012 a positive $\mathrm{EVA}_{\mathrm{p}}$ equal to 1.749.055;

- $\quad$ in the period 2013-2014 a negative $\mathrm{EVA}_{\mathrm{p}}$ equal to -15.488.146. 
Table 4. The value of weighted EVA

\begin{tabular}{ccccccccl}
\hline Period & \multicolumn{1}{c}{$\mathrm{K}$} & \multicolumn{1}{c}{$\mathrm{r}_{\mathrm{p}}$} & $\mathrm{c}$ & \multicolumn{1}{c}{$\mathrm{R}^{2}$} & \multicolumn{1}{c}{ NOPAT $_{\mathrm{p}}$} & \multicolumn{1}{c}{ NOP } & \multicolumn{1}{c}{ COT } & \multicolumn{1}{c}{ EVA $_{\mathrm{p}}$} \\
\hline 2003-2004 & $207.826,61$ & 0,649224 & 4,21 & 0,2286 & $134.926,02$ & $87.701,91$ & $-114.877,36$ & $-740.024,00$ \\
$2005-2006$ & $777.749,97$ & 0,075438 & 3,3 & 0,2286 & $58.671,90$ & $38.136,74$ & $-49.953,84$ & $-2.507 .903,00$ \\
$2007-2008$ & $254.254,22$ & 0,40005 & 4,12 & 0,2286 & $101.714,40$ & $66.114,36$ & $-86.600,66$ & $-945.813,00$ \\
$2009-2010$ & $-53.350,14$ & 1,495044 & 5,72 & 0,2286 & $-79.760,81$ & $-51.844,53$ & $67.909,15$ & $225.402,00$ \\
$2011-2012$ & $-1.071 .443,89$ & 1,147572 & 2,78 & 0,2286 & $-1.229 .559,00$ & $-799.213,35$ & $1.046 .858,83$ & $1.749 .055,00$ \\
$2013-2014$ & $5.286 .691,78$ & 0,530352 & 3,46 & 0,2286 & $2.803 .807,56$ & $1.822 .474,91$ & $-2.387 .189,79$ & $-15.488 .146,00$ \\
\hline
\end{tabular}

Source: our elaboration on "AIDA" data

The results indicate the positive impact of diversification on $\mathrm{EVA}_{\mathrm{p}}$ starting from the period in which Government grant are concentrated (2007-2008). The last period analyzed (2013-2014) shows an inversion; this inversion is to be considered attributable to outdoor environmental factors that have not been taken into account in this study.

\section{Discussion}

This research has explored the links between strategic and financial management. Specifically, the theory that links company diversification strategies to capital structure was questioned and experimented.

Acting as a link between strategic research and corporate finance studies, this study examined how strategic decisions linked to the product can be influenced by financial structure and specifically, how Government grant intervenes to strategic decision process.

Results emerging from questionnaires indicate the considerable weight that public financial grant have in conditioning product policy (adjusted R-Squared equal to 38\%).

To understand how diversification stimulated by Government grant, have influenced the enterprise value, our research suggests a useful method to evaluate cause-effect relationships and a model in the research of created or destroyed economic value.

From the elaboration carried out with EVA, appropriately parameterized, emerges the weight of diversification strategy in the growth or destruction of company value; this weight is estimated equal to $23 \%$.

The analysis shows favorable trend of $\mathrm{EVA}_{\mathrm{p}}$ starting from the period in which Government grants are provide.

Therefore, this study suggests the considerable weight that product strategy has in modifying business economic-financial profiles. Nevertheless, some empirical studies not sustain this hypothesis (Chatterjee, 1990; Yip, 1982). This result is in accordance with Chatterjee and Singh (1995) which highlighted the importance of diversification in the growth of company value and the strong link between sources of financing and adopted strategy.

According to the studies conducted previously (Balakrishnan and Fox, 1993; Barton and Gordon, 1988; Bromiley, 1990; Jensen, 1986), this work has shown that financial strategy is 
influenced by diversification strategy and that capital structure influences simultaneously the relative diversification strategy. Moreover, this study highlights the importance of diversification on firm value creation.

\section{References}

Balakrishnan, S., \& FOX, I. (1993). Asset specificity, firm heterogeneity and capital structure. Strategic Management Journal, 14(1), 3-16. https://doi.org/10.1002/smj.4250140103.

Barton, S. L., \& Gordon, P. J. (1988). Corporate strategy and capital structure. Strategic Management Journal, 9(6), 623-632. https://doi.org/10.1002/smj.4250090608.

Bennet Stewart, G. (1991). The Quest for Value. Harper Collins Publishers, New York.

Bennet Stewart, G. (2000). La ricerca del valore. Una guida per il management e per gli azionisti. EGEA, Milano.

Brealey, R. A., \& Myers, S. C. (1991). Principles of corporate finance. McGraw-Hill, New York.

Bromiley, P. (1990). On the Use of Financial Theory in Strategic Management. Advances in Strategic Management: a research annual, 6, 71-98.

Chatterjee, S. (1990). Excess Resources, Utilization Costs, and Mode of Entry. The Academy of Management Journal, 33(4), 780-800. https://doi.org/10.2307/256290.

Chatterjee, S., \& Singh, J. (1995). The Type of Entered Market and the Mode of Entry: An Examination of Their Simultaneity and Reciprocal Relationship. Working Paper, Case Western Reserve University.

Chatterjee, S., \& Wernerfelt, B. (1991). The Link Between Resources and Type of Diversification: Theory and Evidence. Strategic Management Journal, 12(1), 33-48. https://doi.org/10.1002/smj.4250120104.

Copeland, T. E, Koller, T., \& Murrin, J. (2002). Il valore dell'impresa. Strategie di valutazione e gestione. Il Sole 24 Ore, Milano.

Di Lazzaro, F. (2003). La performance del valore. Per l'analisi aziendale. Giappichelli, Torino.

Donna, G. (1999). La creazione di valore nella gestione dell'impresa. Carocci, Roma.

Ezzamel, M. (1996). La misurazione e la valutazione della performance divisionale. Parametri contabili, finanziari e qualitativi. EGEA, Milano.

Grant, J. L. (2003). Foundations of Economic Value Added. John Wiley and Sons, Hoboken.

Guatri, L. (1991). La teoria di creazione del valore: una via europea. EGEA, Milano.

Jensen, M. C. (1986). Agency Costs of Free Cash Flow, Corporate Finance, and Takeovers. The American Economic Review, 76(2), 323-329. https://doi.org/10.2139/ssrn.99580. 
Kochhar, R (1996). Explaining Firm Capital Structure: The Role of Agency Theory vs. Transaction Cost Economics. Strategic Management Journal, 17(9), http://dx.doi.org/10.1002/(SICI)1097-0266(199611)17:9<713::AID-SMJ844>3.0.CO;2-9.

Lothian, N. (2005). Misurare la performance aziendale. Il ruolo degli indicatori funzionali. EGEA, Milano.

Modigliani, F., \& Miller, M. H. (1958). The Cost of Capital, Corporation Finance and the Teory of Investment. The American Economic Review, 48(3), 261-297.

Myers, S. C., \& Majluf, N. S. (1984). Corporate financing and investment decisions when firms have information that investors do not have. Journal of Financial Economics, 13(2), 187-221. https://doi.org/10.1016/0304-405X(84)90023-0.

Ramanujam, V., \& Varadarajan, P. (1989). Research on corporate diversification: A synthesis. Strategic Management Journal, 10(6), 523-551. https://doi.org/10.1002/smj.4250100603.

Ray, S. (2012). Efficacy of Economic Value Added Concept in Business Performance Measurement. Advances in Information Technology and Management, 2(2), 260-267.

Shil, N. C. (2009). Performance Measures: An Application of Economic Value Added. International Journal of Business and Management, 4(3), 169-177. http://dx.doi.org/10.5539/ijbm.v4n3p169.

Stern, J. M., Shiely, J. S., \& Ross, I. (2001). The EVA Challenge: Implementing Value-Added Change in an Organization. John Wiley and Sons, Hoboken.

Unnisa, N., \& Janakiramudu, P. (2014).Is EVA a Superior Measure of Shareholder Value? Evidence from CNX Nifty Constituent Firms. Asian Journal of Finance \& Accounting, 6(1), 388-401. https://doi.org/10.5296/ajfa.v6i1.5372.

YIP, G. S. (1982). Diversification entry: Internal development versus acquisition. Strategic Management Journal, 3(4), 331-345. https://doi.org/10.1002/smj.4250030405. 